\title{
ABOUT KESH TOPONYM AND ITS LOCATION
}

\section{Shokir Parmanov}

Lecturer The Faculty Of History, National University Of Uzbekistan, Uzbekistan

\section{ABSTRACT}

This article focuses on the Kesh toponym and its localization by researchers, with particular emphasis on the location and localization of the Nautaka area, which is cited in written sources. In particular, recent archeological excavations have focused on the localization of the Nautaka area, which has caused controversy among researchers as to whether it corresponds to the present-day Shakhrisabz and Karshi regions. The Nautaka area mentioned in the written sources can be localized today with the Kesh (Shahrisabz) area.

KEYWORDS: - Nautaka, Kesh, Ksenippa, Nakhshob, Kesh, Shakhrisabz, Oksuv, M.E.Masson, A.Sagdullaev.

\section{INTRODUCTION}

The first information about the Kesh Valley relates to the details of Aleksanadr Makedonsky's campaign to Central Asia. The document, written in the Aramaic language found in Afghanistan, contains information on Kesh [1]. Ancient antiquity is comparable to the Kesh valley by some researchers (E.V.Rtveladze, A.Sagdullaev) in the Nautaka region, mentioned in the works of Greek authors. Nautaka (Navtaka) is philologically translated as "new building", "new place"[2].

The investigator Franz Grene clarifies the Nautaka toponym as "nava-taka" - "a river of real land." From Samarkand to the Iron Gate passed through the cities of Jom, Podayogtepa, kaltaminor and Okrabot. They, in turn, crossed nine rivers (from north to south, Kum River, Ayoqchidarya, Kashkadarya, Oksuv,
Tanhozdarya, Kyzyl-Darya, Langar, Grand Uradarya, Small O'radaryo) [3].

There are two different views on the subject of Nautaka's location. The first group of scientists, M.E.Masson, R.H.Sulaymonov, According to M.Kh.Isomiddinov, Nautaka is considered as the ancient city of Ergurgon.

\section{THE MAIN RESULTS AND FINDINGS}

According to the second group of scientists, Nautaka is an ancient Kesh city. The supporters of this viewpoint are close to reality. Near the city of Erkurgan wasn't the high rocks of the Greek historians, A.Sagdullaev claims that Alexander named Nautaka when he occupied the ancient Kesh.

S.K.Kabanov does not comment on these two views in written sources, but argues that Nautaka and Xenippe are at the top or bottom of the current Kashkadarya region. K.Kabanov 
CURRENT RESEARCH JOURNAL OF HISTORY 2(7): 01-04, July 2021

DOI: https://doi.org/10.37547/history-crjh-02-07-01

ISSN 2767-472X

(C)2021 Master Journals

\section{Crossref dof 81 Google}

Accepted 02 ${ }^{\text {th }}$ July, 2021 \& Published 07thJuly, 2021

views Nautaka as Xinhpapan as a region rather than a city.

There are two sources in the written sources Nautaka and Xenippa, "says S.K. Kabanov, they are called historians and archeologists in the Kashkadarya valley. These regions, of course, coincide with the two ancient peaks of the vineyards - Shakhrisabz and Karshi at the top and bottom of the oasis. But there is a difference in opinion of the researchers on the fact that these names fit into the present. According to S.Kabanov, Nautaka is the upper part of the oasis, and Xenippa is the lower part, ie Ksenippa Nakhshob (Karshi), and Nautaka - Kesh (Shakhrisabz) [4].

And M. E. Masson supports this idea, namely, the upper part of the Ksenippa valley, and Nautaka. The ancient scientist also notes that Navtak - the main city of the lower provinces - will be replaced by the ruins of Erkurgon[5].

The history of the city of Nautaka - Kesh can be found in Chinese written sources. Chinese historians cite different names. One of the Chinese chronicles "Tyanshu" was mentioned in the events of the 656-660 years in the form of Kesh toponimi Kyusha[6].

History of the Han dynasty of the Chinese origin Xanshu contains rich information about the history of the ancient statehood of Uzbekistan. In Xanshu, in the 2nd century BC, one of the five smaller city khanates within the Khanate state referred to the Sushie gou as the Ches khanate or the fortress, and its center, the city called Sushie Cheng, as Shahrisabz[7]. Another source in Beyshi is the Shi or Shi language. He was led by Di-Chje, who first established diplomatic relations with the Chinese ruler Da-yi (605-616) in Sughd[8].

Chinese historians write the Kesh (Shi) as "shi", while in the past they were pronounced as "Siesiau", "Siausie", "Sie". According to N.
Bichurin's transcript, this inscription is in the form of "shi", but it does not mean that Chinese sources are not the same as the old cache[9].

The cave's toponym was originally found in the writings of the Sassanid ruler, Shopur I (242273). Here, Shopur I describes the borders of its state, including the borders that reach Central Asia's Kash, Sogd and Shash mountains.

Kyusha in Tiananshi was noted in the events of 656-660 years. The same name appears here in the coins of the King of Kesh, Ikhrid, who ruled in the middle of VIII century.

So, aforesaid information is witness to existing the name of Kesh from BC III toBC VIII, however this toponym wasn't used before BC III that's wrong idea. According to Sh.Kamoliddinov, the name of Kesh firstly was used the end of VII age and the early of VIII age in there three differences of the town:Kash, Kish and Kesh are mentioned. In the sogd texts of the coins is always given without wovel as KS. In scientific literaries the name of Kesh expressed but Yokut thought about the toponym which its real name is Kish or Kiss,accordang to Ibn Mukul.(10801081) [10].Yogut is mentioned that Kesh is the prononounciation of the arabian. In accordance with Yokut, it's pronounced it among local people as Kesh XI century[11].

We can met the full writing in the form of Szyuyshuana as well as Szyuysha-Kyuysha in Chinese language[12]. These two forms might have existed at the same time, but later in the VIII the century the short form of the name KeshKish appeared instead of Keshan -Kishun.

It was investigated that the old name of Tashkent was called as a form of Choch which had been called Chochon[13].

Many researches considered that Kash and Kesh names which means the same place,in Kashkadarya valley. According to V.P. Luko's opinion, it was assumed that place might have 
CURRENT RESEARCH JOURNAL OF HISTORY 2(7): 01-04, July 2021

DOI: https://doi.org/10.37547/history-crjh-02-07-01

ISSN 2767-472X

(C)2021 Master Journals

\section{Crossref dof 81 Google}

Accepted 02 ${ }^{\text {th }}$ July, 2021 \& Published 07thJuly, 2021

been Koshgar[14].

You can meet the only form "Kish" in the work of "Hudud al-alam". You can also come across to the words "Keshliklar" and "Keshda yashovchilar" in sogdian sources Mug' of Tadjikistan[15].

\section{Conclusion}

In conclusion in the works of historians and geographs of the Middle age had less information about Kesh, but they informed that the walley was rich in natural sources and had many villages as well as cities. The information of manuscripts give such opportunity to estimate historical-cultural process of that time as well as archeological investigations[16].

Sources of Temurids period inform about the history of Kesh(Shakhrisabz). They are based on the activities of Temurid's state. The name "Shakhrisabz" begin to be used as well as "Kesh" in that time. But the name "Shakhrisabz" was firstly used in the topographic maps of Russia as a toponym.

\section{REFERENCES}

1. Саул Шакед. Раннее упоминание о городе Нахшаб // Қарши шахрининг жахон цивилизацияси тарихидаги ўрни. Тошкент - Қарши, “Фан”, маъруза, 2006, 34 - б.; Франц Грене. Новые свидетельства о Нахшабе и Кеше античного периода. // Қарши шахрининг жахон цивилизацияси тарихидаги ўрни. Тошкент - Қарши, “Фан”, маъруза, 2006, 35 - б.

2. Қадимги Кеш-Шахрисабз тарихидан лавхалар. Т., Шарқ, 1998. 18-бет.

3. Франц Грене. Заметки о топониме Наутака // Шахрисабз шахрининг жахон тарихида тутган ўрни, хал. Илмий кон., маърузалар, Т., Фан, 2002, $10-11$ б.
4. Кабанов С.К. В оазисах и степях Кеша и Нахшаба. Т., “Узбекистон”, 1988, с. 37.

5. Равшанов П. Қарши тарихи. Т., Янги авлод, 2006, 107-б.

6. Камолиддинов С.Ш. Историческая география Южного Согда и Тохаристана по арабоязычным источникам IX - XIII вв. Т., Узбекистан, 1996, с.14.

7. Аитбоев А.. "Хан сулоласи тарихи" китобида Шахрисабз хақида маълумот // Шахрисабз шахрининг жахон тарихида тутган ўрни, хал. Илмий кон., маърузалар, Т., Фан, 2002, 32 б.

8. Бичурин Н.Я. (Иакинф) Собрание сведений о народах, обитавших в Средней Азии в древние времена. М - Л, Из-во АНССР, 1950-1953, т 2, с. 286.

9. Ходжаев А. Наиболее ранние сведения китабских источников о Шахрисабзе. // Қарши шахрининг жахон цивилизацияси тарихидаги ўрни. Тошкент - Қарши, “Фан”, маъруза, 2006, 124 - б.

10. Бартолъд В.В. Кеш, Соч., Т.3. М., 1965, С. 460.

11. Камолиддинов Ш.С. Историческая география Южного Согда и Тохаристана по аробоязычным источникам IX - XIII вв. Т., Узбекистан, 1996, с.14

12. Бичурин Н.Я. Собрания сведений о народах, обитавших в Средней Азии в древние времена. М.-Л., 1950. С. 316.

13. Ртвеладзе Э.В. О ранних монетах Чача /Чачана/ и подлинном названии области // Археология, нумизматика и эпиграфика Средней Азии. Самарканд, 2000. С. $147-149$.

14. Луконин В.Г. Культура Сасанидского Ирана. М., 1969, с. 126. 
CURRENT RESEARCH JOURNAL OF HISTORY 2(7): 01-04, July 2021

DOI: https://doi.org/10.37547/history-crjh-02-07-01

ISSN 2767-472X

(C)2021 Master Journals

\section{Crossref do) 81 Google}

Accepted 02 ${ }^{\text {th }}$ July, 2021 \& Published 07thJuly, 2021

15. Камолиддинов С.Ш. Историческая география Южного Согда и Тохаристана по аробоязычным источникам IX - XIII вв. Т., Узбекистан, 1996, с.15.

16. Муқаммаджонов А.Р. “Кеш” ойконими ва “Кат” субстратининг этимони // Шахрисабз шахрининг жахон тарихида тутган ўрни, хал. Илмий кон., маърузалар, Т., Фан, 2002, 15 б.

17. Anatoliy Sagdullaev, Fayzulla Ochildiev, Akhmad Kholikulov, Alisher Shaydullaev, Jasur Togaev. Problems Of Cartography Of Ancient EthnoCultural Processes In Central Asia // INTERNATIONAL JOURNAL OFSCIENTIFIC- \& TECHNOLOGY RESEARCH VOLUME 9, ISSUE 04, APRIL 2020. P. 745748.

18. Ochildiev, F. B. (2019). Trade relations between Bukhara - Russia in the second half of XVIII century - in the XIX century. ISJ Theoretical \& Applied Science, 05 (73), 484-487.

19. Ochildiyev, F. (2019). TRADE RELATIONS BETWEEN BUKHARA AND RUSSIA IN THE SECOND HALF OF THE XIX CENTURY-THE BEGINNING OF THE XX CENTURY//Social Sciences: Achievements and Prospects Journal 3 (11), 2019/OEAPS Inc.(Open European Academy of Public Sciences); Chief Editor Mark Freeman-Barcelona, Spain. 16.03. 2019: OEAPS Inc., 2019.-pp. 55-60.

20. Ochildiev, F. B. (2020). Social relationship and tax types in the XIX-XX century in Bukhara Emirate. International Journal of Scientific and Technology Research, 9(1), 723-729.

21. Parmanov, S. E. (2019). The urban culture of Kesh oasis in Temurids period. ISJ Theoretical \& Applied Science, 06 (74), 240-243. 